Article

\title{
Unfolding Education for Sustainable Development as Didactic Thinking and Practice
}

\author{
Katrine Dahl Madsen \\ Department of Education, Aarhus University, Tuborgvej 164, Copenhagen NV 2400, Denmark; \\ E-Mail:kdma@dpu.dk; Tel.: +45-87-16-38-09
}

Received: 30 July 2013; in revised form 19 August 2013 / Accepted: 26 August 2013 /

Published: 4 September 2013

\begin{abstract}
This article's primary objective is to unfold how teachers translate education for sustainable development (ESD) in a school context. The article argues that exploring tensions, ruptures and openings apparent in this meeting is crucial for the development of existing teaching practices in relation to ESD. The article draws on doctoral research involving interviews with researchers and teachers who have collaborated in ESD research and development projects at primary and secondary schools in two different countries, Denmark and Ireland. It is the teachers' perspectives on the projects which form the analytical foundation; thus, it is the practices as seen from the 'inside'. Furthermore, ESD practices are considered in a broader societal perspective, pointing to the critical power of the practice lens.
\end{abstract}

Keywords: education for sustainable development; teaching practices

\section{Introduction}

There is growing awareness that education can play a key role in tackling the challenges of the 21 st century. The term education for sustainable development (ESD) has gained currency as a catchall term for educational approaches to issues such as climate change, unsustainable living and growing inequity in access to natural resources. Internationally this has been supported by the UN Decade of Education for Sustainable Development (2005-2014). Core themes of sustainable development-the impact of contemporary actions on future generations, and of local actions on people on the other side of the world-demand pedagogical approaches emphasizing visions, sociological imagination and empathy. Furthermore, the rapid rate of change and high degree of complexity within modern societies emphasizes the importance of cross-disciplinarity in teaching about the multidimensional 
issues of sustainability, as well as the importance of enhancing young people's ability to cope with uncertain and shifting knowledge, as described by Scott and Gough [1].

Recent research stresses, however, that the work with education for sustainable development is often not very well rooted in the existing school system [2,3]. It competes with a number of other issues, with the broad and relatively loose definition of ESD constituting a barrier to its integration within a system still characterized by the fixed structures of subjects, lessons and curricula. ESD is a contested concept and open to a number of interpretations. Against this background it seems crucial to consider teachers' perspectives, their everyday lives and the socio-economic context for their work if we want to improve sustainability education in schools [4].

As stressed by Andersen [5], all new knowledge introduced in schools must be contextualized in relation to the everyday life and teaching practices of the school. What, then, characterizes the everyday life and teaching practices of the school within which ESD should be integrated? The following themes have been emphasized as characteristic of a teacher's practice by Arfwedson (in Andersen) [5], and might be recognized by some teachers: multidimensionality, which refers to the need for teachers to handle a multitude of different situations at the same time, requiring constant choices; simultaneity, which stresses that all these issues and choices happen at the same time; rapidity, which refers to the need to maintain a certain tempo and structure to keep the students' attention; unpredictability, which stresses that the teacher must have a number of alternatives for the lesson up her sleeve at all times in order to cope with the unexpected-also called competences in reflections-in-action [6]. Furthermore, the teaching is characterized by publicity, due to the number of people present, but not directly participating in dialogue. Finally, historicity is stressed as a characteristic of the classroom as teacher and students share experiences here which are also built upon in subsequent lessons. If we follow this description, the teacher's everyday practice appears rather demanding, unpredictable and chaotic. ESD, characterized by multidimensionality, uncertain knowledge and open learning processes, would then appear a good match with the existing classroom learning context. However, it is perhaps understandable that many teachers have no desire to add to the chaos, complexity and unpredictability by integrating ESD within their teaching practice.

At the core of my research lies a curiosity regarding how the ideas and principles of education for sustainable development are practiced and contextualized by teachers in various subjects. I am interested in how education for sustainable development unfolds as didactical thinking and practice, in order to identity ruptures, tensions and openings in relation to future work with sustainability in schools. The concept of didactics, as defined by Schnack, highlights the many simultaneous forms of learning and that learning also occurs through the form, not only the content, of teaching, based on a notion that no choices are "natural" [7]. This points to the importance of what is taught, how it is taught and why it is taught, and the question of what you educate for-as a question to be posed in response to the question of "what works" [7,8]. The school can be treated as a passive arena for implementing external political aims and targets for sustainability, or as an active player, emphasizing the importance of the school environment, conditions and meaning making for education for sustainable development [9]. This study is based on the latter understanding of the school, and the notion that there are active processes of reinterpretation and translation taking place in the teachers' encounter with ESD.

Earlier studies have addressed the issue of teachers' thinking and practices in relation to environmental education (EE)/ESD, among these Sund \& Wickman [10]; Wickenberg [11]; 
Breiting and Schnack [12]; Meyer [13]; Sandell, Öhman \& Östman [14]; Hart [15]. Various teaching strategies have here been identified; e.g., fact-based, normative and pluralistic, which exist as parallel and partly overlapping approaches [14]. A main difference highlighted in these studies is whether the focus is more on fixed aims of developing responsible and environmentally friendly behavior, or on participatory processes and critical thinking. The importance of including a structural level in anchoring the work with EE/ESD in schools is also stressed, as national policies and strategies seem crucial to support and legitimize the work with environmental education and sustainability in schools, which often lack a curriculum mandate $[15,16]$. The aim of this study is to contribute to the field of practice-based studies of EE/ESD, focusing on teachers' perspectives and the transformation processes taking place in the work with ESD in a school context. It has a particular focus on the practice as "seen from inside", and on what the practice "does" [17] in terms of tensions, ruptures and openings in relation to existing teaching practices and the future work with education for sustainable development in schools. The research is based on the notion that the specific reflects more general issues, and as such will include themes of more broad relevance within the work with education for sustainable development in a school context [18,19]. In this sense, the teacher's story is both her own specific story, but also a story about some of the struggles related to working with ESD which others might relate to.

Firstly, the research project will be presented, including the data collection methods and the theoretical approach. Next, the analytical findings regarding the teachers' encounters with ESD will be presented thematically. The article concludes by summarizing and discussing the analytical findings, structured around the issues of ruptures, openings and tensions.

\section{Background}

In Denmark, the historical development of education for sustainable development has been described as an ongoing process, from nature education to environmental education, in a broad sense, to ESD. In addition, the critical dimension of ESD relates to a tradition of bildung (political education) in the Danish school system [2,7]. The concept of sustainable development has, since a school reform in 2009, formed part of a number of subjects in the Danish curriculum - from history to science to art classes. Furthermore, environmental education and sustainability form a cross-curricular theme. However, the ideas of education for sustainable development are not reflected in the curriculum. In Ireland, both environmental education and development education form part of the historical background for the work with ESD in schools [20].

The article draws on a doctoral study, involving interviews with researchers and teachers who have collaborated on two research - and development projects in primary and secondary schools in Denmark and Ireland during the period 2008-2009. The two research and development projects were carried out as part of the UN Decade of ESD; in the case of the Irish project, the project also formed part of the Irish Regional Center of Expertise on Education for Sustainable Development (RCE-Ireland) which forms a national network aimed at developing and disseminating education for sustainable development. Both projects were based on principles of participation, critical thinking, ownership and experimentation. The researchers introduced the teachers to certain key principles and issues of ESD, partly inspired by the UN definition of ESD, partly drawing on existing conceptual development of environmental 
education, ESD and action competence [7]. The idea in both projects was to introduce ESD as a "perspective through which to understand the world", rather than a toolbox or an extra-curricular activity. This is based on the notion that sustainability constitutes a global challenge, with relevance for all subjects and all levels of education. Randomly selected teachers from a number of subjects and levels were invited to participate. As the researchers invited the teachers to participate in the development project, their intention was never to offer some form of predefined ESD package, but to introduce various ways of doing ESD in schools, and to support the teachers' own development of sustainable development teaching. The research and development projects frame this study; however, the main focus of this article will be the teachers' encounter with ESD, rather than the cooperative processes in these projects or the RCE framework. Seven teachers from various subjects; science, languages and social sciences, teaching in primary and secondary schools in Denmark and Ireland have been interviewed for this study, based on the belief that ESD is relevant for all levels in all subjects, and that no child is too young to learn about sustainability [12]. The interviews were carried out as qualitative individual interviews during visits at primary and secondary schools in the two countries. The interviews were subsequently transcribed and analyzed in an abductive process, jumping back and forth between theory and empirical data. The intention was not to compare-focusing on similarities and differences among the subjects and development projects in Ireland and Denmark — but rather to gain insight into the processes whereby ESD takes form as didactic practice. Participant observation within the framework of the Danish Regional Center of Expertise (RCE-Denmark) further supplemented the analysis of the teacher interviews.

\subsection{Theoretical Approach-A Practice Lens}

The research has been driven by an interest in how teachers do education for sustainable development, what they do, and "what doing it does", inspired by practice epistemology as presented by Gherardi [17,21] and Schön [6]. This focus stems from a critique of a technical-rational epistemology, and the notion that it is possible to set clear goals and subsequently identify clear approaches and methods to reach these goals. As stressed by Andersen [5], teachers' work is often thought of as easier to plan than it actually is. As such, it is not sufficient to present and introduce ESD as a new field or new research; it requires support and must, as all new knowledge, be contextualized in relation to the everyday life and teaching practices of the school. On this background, the key questions for the analysis have concerned how education for sustainable development is framed and named by the teachers [6]. The focus is therefore not only on the solutions suggested, but also on how problems and challenges are defined and contextualized. According to Gherardi, a practice can be read from "outside", from "inside", and from what the practice "does" in society. The main focus in this article will be practice as seen from "inside"-from the perspectives of the involved teachers. I will further discuss what "doing the practice does", which points to the critical power of the practice lens [17,21]. The concept of practice includes intentional actions and the habitual aspect, as well as social recognition:

As practices are performed they introduce an ordering of human and non-human elements - an ordering which, though fragile, temporary and constantly threatened by disorder, becomes embedded in a network of practices anchored to each other ([17], p. 35).

The study is based on the concept of situated rationality; that multiple rationalities exist and that "rationality" is always dependent on the given situation and context. The practice lens includes both 
discursive practices - how teachers do ESD when they talk - and the tacit and embodied dimensions, as well as artifacts forming part of the practice. The metaphor of translation stresses the collective interpretations taking place when different practices interweaves, and the importance of artifacts, mediating in these processes:

The metaphor of translation is a way to describe movements between different forms of knowledge and cultural practices, but also of technology and artifacts. It has both a geometric and semiotic meaning. Translation is both the movement of an entity in space and time and its translation from one context to another - as in translating from one language to another, with the necessary transformation of meaning that this always implies. ([17], p. 62).

The study of practice is also a way to study learning. Surprise and uncertainty become vital, as they make us reconsider our actions and understandings, perhaps leading to new understandings and actions [6]. This also points to the importance of identity and the process of becoming an ESD teacher, and it involves tensions in relation to existing practices and the institutional anchoring of these practices, building on the notion that society is produced and reproduced in simultaneous processes [22].

A qualitative and explorative method was employed, driven by curiosity. The aim has been to listen from 'inside' the profession [23], involving a sometimes difficult balancing act between intimacy and detachment, with multiple voices mingling with one another in the research. A further aim has been to discuss these insights in relation to key ideas and principles of ESD. The interviewees are perceived as competent interpreters of the field, and the aim has been to learn from them. However, the teachers have not been selected as standard-bearers, and the aim has not been to identify some kind of "best practice"-rather just practice. The teachers have chosen to participate in the development projects on ESD in Denmark and Ireland, and as such they show an interest in ESD, or the research and development projects - or both. It is, however, difficult to state where they are placed on a continuum from ardent supporters to "not interested".

\section{Results and Discussion-the Teachers' Encounter with ESD}

The following presents the core findings of the analysis regarding the teachers' encounter with ESD in a school context. Issues addressed are: A dramatic encounter, Processes of concretization, Insisting on hope and belief in the future, and finally Anchoring ESD at the school.

\subsection{A Dramatic Encounter}

ESD, as it is introduced in the research and development projects, clearly forms a challenge for the participating teachers. The combination of the concepts education and sustainable development, as introduced in the UN Decade of ESD, is new to the teachers, and the teachers were initially unsure of how to tackle the issues and were struggling as to how to start the teaching. Especially the open form of the concept and the loosely defined content are stressed as challenging. As expressed by one of the Irish language teachers:

"I suppose that's why we probably struggle at the start about; what to do, what to do? I remember e-mailing the researcher, I said; what should I do, what do I have to do? It was so broad; it was difficult in the start to know; what do we do?" 
In line with this, one of the Danish science teachers stresses: "...it is not a path that has been established, sustainability in school... it is definitely not an asphalted road". The ideas and principles of education for sustainable development appear as a dramatic encounter for both Danish and Irish teachers. Working with both the self-reflexive aspect, which is inherent in the introduction of ESD in the two projects, and a personal and professional development focus, forming part of the research and development projects, has given the projects character of a kind of "experimental space" — a space, which the teachers seem to find difficult to inhabit. They struggle to "grasp" methods and content and to concretize and decode the "right way" to do ESD. In line with Schön [6], this space, characterized by insecurity and confusion, is a good starting point for new practices. In the processes of grasping and approaching ESD, teachers seek to identify the didactical what?

\subsection{Processes of Concretization}

While the lack of a clear framework and content for working with ESD can lead to uncertainty and confusion among teachers, this same openness and flexibility also seems to increase teachers' willingness to integrate ESD within their teaching as it allows them to decide for themselves how, when and what to include. In the attempts to "grasp" ESD, different processes of concretization are apparent. One is to integrate elements and aspects which seem meaningful and relevant in relation to the subject and the already planned course. The Irish language teachers, for instance, have concentrated on teaching the main concepts in Spanish and the communicative aspect. As stressed by one of the language teachers: "You see, because we come from languages, we would always have communication". As such, this also reflects the habitual dimension of the practices. Another form of concretization, for both primary and secondary school teachers, is the use of artifacts such as bananas, postcards, cell phones, water bottles and organic food. These artifacts are used as a basis and a recurring point of reference for the teaching and the students' group work, for discussing ecological footprints and fair trade, and to support the students' participation in forming, investigating and communicating the issues. One example of this was in a language class, where a banana formed the starting point for the teaching. Each student was given a banana and the class explored and discussed questions such as: where did the banana come from, how much energy has been used for transportation of the banana, and what is the ecological footprint of the banana. The artifacts offer a concretization, which the teachers seek, and reduce some of the complexity of sustainability, while still offering a way to discuss and reflect on the temporal and spatial dimensions and the coherence of the social, economic and environmental dimensions. The use of images also seems to strengthen the self-reflective and critical dimension of ESD, and to activate knowledge within an area where little language exists as yet. An example is provided by a project in one of the Danish schools. In this case, the pupils conducted interviews with elderly and middle-aged people in their local community about the use of a particular natural resource. They asked them how the chosen natural resource was used in the past, how it is used in the present, and how it will be used in two possible futures-one being the future they expect, the other the future they hope for. Back in class, the pupils illustrated the points from the interviews on four different posters: past, present, and the two future scenarios. On this background, the students discussed and reflected on the issues raised on the posters. Thus, the approach involved aspects of visualization, reflexivity and conceptual development in relation to ESD. In these two cases, the use of bananas and 
posters seems to contribute to challenging traditional hierarchical relationships, where the teacher is viewed as the source of knowledge, and strengthening the participatory, evocative and imaginative elements of ESD. As such, the use of artifacts also seems to permit some actions, while preventing others [17]. A third process of concretization, as seen in examples involving teachers within various subjects, is to draw upon your own life and your own life experiences. Teachers draw on personal engagement in environmental issues, stories from travels to foreign countries and colleagues' travel pictures, and stories and materials are introduced into the teaching. The personal nature of such teaching does, however, imply a certain degree of arbitrariness - not all teachers are able to draw upon trips to Guatemala or participation in a "green families" project. This approach is also described by teachers as quite demanding, as there is no support from tailor-made teaching materials, as stressed by one of the Irish teachers:

"I think actually, once you had got started and you did something with it, that it was easy to put into our curriculum, that's what I found. Because a lot of the time you are too structured, and confined to what you have to do. And... with enough planning and thinking about it, I found that you could very much link it into how you taught, but it did take a big effort. It did take a lot of effort and commitment, but if you are willing to do that, it would... and it is a project that they remember."

The various ways of knowing and learning: visual, aesthetic and narrative; using images, stories and artifacts, challenge the notion of the teacher and the textbook as the focal points of teaching, and invite us to start somewhere else. As such, the sustainability teaching also challenges a traditional understanding of experts as "...someone with mastery over a body of knowledge and its relevant techniques" ([24], p. 29). This places new demands on the teacher: to handle uncertain knowledge and open-ended learning processes and to accept that working with ESD requires broader knowledge than specific subject-related knowledge. As such, both teachers and students become learners. Whereas teachers grasp artifacts and personal experiences, and incorporate ESD elements as seems appropriate to the specific subject, they never refer to the international and national policy frameworks for ESD. When referring to the existing curriculum, it is mainly as something you have to "get around" in the work with ESD.

\subsection{Insisting on Hope and Belief in the Future}

The teachers' experiences reflect an insistence on hope and trust in the future. The alternative, according to the teachers, is scare stories about the future, apathy and admonishment. The dimension of critical thinking and awareness building is clearly a part of ESD which the teachers embrace to counterbalance what they see as tendencies towards individualism, passivity and ignorance among their students. Central phrases in the teachers' argumentation are: "awareness building", "taking responsibility", "thinking outside the box", "broadening their minds", "daring to mean something". As part of this argumentation, the action-oriented aspect is underlined as teachers stress that students are taking the initiative, working independently and proactively, as stressed by one of the Irish teachers:

"We would be introducing them to the whole idea of sustainable development and making them aware of, you know the world around them. Because, like I said, even at the age of sixteen, seventeen, they have no clue... they are just like: yeah well it will happen to me! So getting them 
to get up on their feet and go and find something, but they have to get up, to walk around, to find information on their own."

The teachers seek support in the work with ESD, but do not question the underlying assumption: that sustainability is a necessary part of teaching in schools. Commitment is a key word when the teachers talk about their work with ESD, "fantastic", "students loved it", "I love it", "enriching", "meaningful", are some of the responses from teachers to working with ESD. One of the Irish teachers formulates it as follows: "You know, if you are a teacher, that's what you want. You want to be doing stuff that is educational. It just fits into your own belief system, really". The teachers all refer to a personal commitment to environmental and global issues when they argue for the importance of teaching for sustainability, and their stories weave together personal and professional engagement, as expressed in the following passage:

"I have to say, like, a lot of the students, they would have been very well travelled; they came from all these different countries and I found that ... even things like the recycling. How many things we throw away, you know: plastic bottles, cans, I mean all the things that can be recycled. I mean, in my home I recycle everything... And I suppose it kind of amazes me that people are so-ignorant is the wrong word, I suppose they lack knowledge about it, they lack a lot of knowledge."

As such, the work with ESD also seems to provide a bridge between personal and professional engagement. The teaching reaches beyond the classroom and interacts with the teachers' personal lives. Personal involvement is key to learning for sustainability for both teachers and pupils. The personal involvement of students is primarily ensured by teaching which goes beyond the four walls of the classroom by incorporating excursions involving local people and businesses, local agriculture, and students from other classes. Working with real issues - issues that are not used just to illustrate a point, but which form a legitimate and necessary foundation for learning-helps ensure genuine engagement with ESD.

\subsection{Anchoring ESD within the School}

Gherardi stresses how practices form “...an ordering which, though fragile, temporary and constantly threatened by disorder, becomes embedded in a network of practices anchored to each other" ([17], p. 35). As a rather new didactical practice, the question is how ESD can, in a longer-term perspective, be anchored within the schools, how space is created, and what might form "anchoring points" for such efforts [25]. In the teacher interviews, the introduction of ESD within schools is described as "small drips", "small footprints" and "fragments". Some of the teachers suggest that ESD should have a full mandate, being a "must" and not a "could". They identify space for ESD, either as a cross-disciplinary theme implemented throughout the curriculum, an independent subject, or as a theme the whole school works with for a period. Changes in terms of colleagues, teaching teams and lesson plans are all stressed as conditions which make it difficult to remain focused on the work with ESD. In the long run, it seems difficult to take the lead as "agents of change". As stressed by a Danish science teacher "I am going to initiate the other teachers, and at some point they were in, and then: uh - nothing really happened. And then I have to be very pushy. And I don't really have the energy to 
do that." Time constraints, tests and a growing demand for detailed planning of the lessons are also emphasized by the teachers as conditions which make the work with ESD difficult at their schools. On the other hand, the Danish teachers also take advantage of the traditional freedom of methods in the Danish school system, and find space within the existing structures. As stressed by one of the Danish teachers:

"If there are limits, it would be this whole exam and test culture, involving very specific demands.

It might be a restriction, but usually there will be space. Otherwise the teacher will make space, we always did. Then we plan an alternative session, a project week or something like that, right."

However, if ESD is to form more than 'small drips', supporting structures at various levels seem necessary.

\section{Conclusions}

Focusing on what "doing the practice does" [17], the following discussion will address some of the ruptures and tensions apparent in relation to existing practices while also exploring perspectives for the future work with education for sustainable development in schools.

\subsection{Ruptures}

ESD, as it is presented in the research and development projects, constitutes a dramatic meeting and a rupture in relation to existing teaching practices. Especially the self-reflexive character of the concept and the loosely defined form seem to be a challenge. The teachers seek the didactical what and how through different processes of concretization; e.g., drawing on their own life experiences, to let concrete artifacts form the starting point, and adapting ESD to the different subjects, concentrating on, for instance, the communicative aspects of sustainable development. As didactical practice, education for sustainable development seems to challenge an understanding of the teacher and the textbook as focal points of teaching and learning and invite a different approach. As part of this, various ways of knowing and learning are explored-narrative, visual and intuitive. Hereby, the teacher is also invited to work with her own values and preferences in relation to sustainability issues, as stressed by Scott and Gough [1].

\subsection{Tensions}

As stressed by Schön [6], the solution to a given problem depends on how it is defined and framed. Teachers problematize that ESD is a "could" but not a "must" - that it is not a separate subject or course, accompanied by instructions and materials ready for use. Based on this definition, the solution would be to integrate ESD within the school as an independent subject or clearly defined obligatory course; however, such integration risks sacrificing central aspects of ESD, including the open learning processes and cross-disciplinary approaches to handling complex issues. On the other hand, teachers' concerns regarding lack of space and opportunity to integrate ESD within a school system characterized by a growing demand for detailed planning, evaluations and time constraints must be taken seriously. The teachers struggle to "get around" the existing curriculum and the segregation of disciplines, and in the long run the position as lone agents of change is clearly difficult to maintain. Anchoring the work in teaching teams seems to support the movement towards becoming "ESD teachers" 
by supporting the development of a professional language and a repertoire of stories, experiences and artifacts to provide inspiration concerning an issue in which no one is an expert. The visibility, and the resulting opportunity for recognition from colleagues, leaders and parents, also seems to support the movement towards becoming an ESD teacher. Meanwhile, the ever-changing composition of teams and classes are conditions that seem to make it difficult to keep a focus on the work with ESD.

\subsection{Openings}

ESD seems to offer a community of meaning for both teachers and students around the common engagement with real problems and issues involving local stakeholders, other students, family etc. As stressed by Schnack [7] and Biesta [8], the didactical question of why reminds us of the overall purpose of education. As such, the critical dimension of education for sustainable development seems to mediate in the sense that teachers grasp the critical aspects inherent in ESD as a response to tendencies towards ignorance and passivity which they witness among their students. The critical, democratic educational ideal seems to allow education for sustainable development to be integrated as part of the didactical thinking and practice within the different subjects - teachers seek support in their efforts, but do not question the relevance of the work.

Thus, various forms of supporting structures seem crucial if the work with sustainability is to be anchored within the school. Wickenberg [11,16] has emphasized how norm supporting structures are crucial — both in the form of international and national policies and on a school level—if the work with $\mathrm{EE}$ and ESD is to be anchored at the school in a longer term perspective. Development projects in cooperation with external stakeholders could here play an initiating and supportive role. Other supporting structures could be practice-based in-service training, and anchoring of "the experimental space" in itself at the school.

\section{Acknowledgments}

I would like to thank Danish and Irish teachers and researchers for their participation in the research and colleagues from the Research Programme in Learning for Care, Sustainability and Health at the Department of Education, Aarhus University, for inspiration and critical feedback.

\section{Conflicts of Interest}

The author declares no conflict of interest.

\section{References and Notes}

1. Scott, W.; Gough, S. Sustainable Development and Learning: Framing The Issues; Routledge: London, UK and New York, NY, USA, 2003.

2. Breiting, S.; Wickenberg, P. The Progressive Development of Environmental Education in Sweden and Denmark. Environ. Educ. Res. 2010, 16, 19-37.

3. Stevenson, R.B. Schooling and Environmental/sustainability education: from discourses of policy and practice to discourses of professional learning. Environ. Educ. Res. 2007, 13, 265-285. 
4. Lotz-Sisitka, H. An Opening Dialogue with Think Pieces and Feature Articles on Learning in a Changing World. South. Afric. J. Environ. Educ. 2007, 24, 8-19.

5. Andersen, P.Ø. Padagogik, udvikling og evaluering - om padagogiske udviklingsprojekter (Pedagogy, development and evaluation - about education development projects); Hans Reitzels Forlag: Copenhagen, Denmark, 2002.

6. Schön, D. The Reflective Practitioner: How Professionals Think in Action; Basic Books: New York, NY, USA, 1983.

7. Schnack, K. Action Competence as Educational Ideal. In The Internationalization of Curriculum Studies; Donna, T., William, E.D., Hongyu, W., William, F.P., Eds.; Peter Lang Publishing: New York, NY, USA, 2003.

8. Biesta, G.J.J. Why 'What Works' Still Won't Work: From Evidence based Education to ValueBased Education. Stud. Philos. Educ. 2010, 5, 491-503.

9. Jensen, J.M. Sundhedsfremmende settings (Health Promoting Settings). In Sundhedspcedagogik $i$ sundhedsfremme (in Danish); Simovska, V., Jensen, J.M., Eds.; Gads Forlag: Copenhagen, Denmark, 2012.

10. Sund, P.; Wickman, P.-O. Socialization content in schools and education for sustainable development- I . A study of teachers' selective traditions. Environ. Educ. Res. 2011, 17, 599-624.

11. Wickenberg, P. Norm Supporting Structures-Environmental Education in Schools. In Normstödjande strukturer. Miljötematiken börjar slå rot $i$ skolan (in Swedish); Studies in Sociology of Law: Lund, Sweden, 1999.

12. Breiting, S.; Schnack, K. Education for Sustainable development. Experiences from the first ESD Schools in the Decade of ESD. In Uddannelse for baredygtig udvikling $i$ danske skoler: Erfaringer fra de første TUBU-skoler i Tiåret for UBU (in Danish); Aarhus University: Aarhus, Denmark, 2009.

13. Meyer, M. Ecosustainability and Quality in the school system: Schools and Environmental Education Centers as partners in an Action Research Process. In Reflective Practice in Teacher Education; Kyburz-Graber, R., Hart, P., Posch, P., Robottom, I., Eds.; Peter lang: Bern, Switzerland, 2006.

14. Sandell, K.; Öhman, J.; Östman, L. Education for Sustainable Development. Nature, School and Democracy; Studentlitteratur: Lund, Sweden, 2003.

15. Hart, P. Problematizing Enquiry in Environmental Education: Issues of Method in a Study of Teacher Thinking and Practice. CJEE 1996, 1, 56-88.

16. Wickenberg, P. Norm supporting structures in environmental education and education for sustainable development, Per, W., Harriet, A., Lena, F., Gustav, H., Johan, Ö., Eds.; Studentlitteratur: Lund, Sweden, 2004.

17. Gherardi, S.; Davide, N. Organizational Knowledge: The Texture of Workplace Learning; Blackwell Publishing: Oxford, UK, 2009.

18. Flyvbjerg, B. Making Social Science Matter: Why Social Inquiry Fails and How It Can Succeed Again; Cambridge University Press: Cambridge, UK, 2001.

19. Negt, O. Sociologisk fantasi og eksemplarisk indloering (in Danish); Kurasje: Copenhagen, Denmark, 1981; pp. 7-28. 
20. Osler, A.; Vincent, K. Citizenship and the Challenge of Global Education; Trentham Books: London, UK, 2002.

21. Gherardi, S. The critical power of the 'practice lens'. Manag. Learn. 2009, 40, 115-128.

22. Giddens, A. The Consequences of Modernity; Polity Press: Cambridge, UK, 1990.

23. Finlay, L. Dancing Between Embodied Empathy and Phenomenological Reflection. IPJP 2006, 6, $1-11$.

24. Fischer, F. Citizens, Experts, and the Environment: The Politics of Local Knowledge; Duke University Press: Durham, UK, 2000.

25. Læssøe, J.; Schnack, K.; Breiting, S.; Rolls, S. Climate Change and Sustainable Development: The response from Education. Available online: http://www.intlalliance.org/fileadmin/user_upload/ documents/DPU_recommendations.pdf (accessed on 27 August 2013).

(C) 2013 by the authors; licensee MDPI, Basel, Switzerland. This article is an open access article distributed under the terms and conditions of the Creative Commons Attribution license (http://creativecommons.org/licenses/by/3.0/). 